\title{
Acquisition of family farm foods for school meals: Analysis of public procurements within rural family farming published by the cities of São Paulo state
}

\author{
Aquisição de alimentos da agricultura familiar \\ para a alimentação escolar: análise das \\ chamadas públicas de municípios \\ do estado de São Paulo
}

Ana Laura Benevenuto de AMORIM ${ }^{1}$

Veridiana Vera de ROSSO ${ }^{2}$

Daniel Henrique BANDONI ${ }^{3}$

A B S T R ACT

\section{Objective}

To assess the food profile in the public procurement within rural family farming for the acquisition of family farm foods for the National School Feeding Program in the cities of São Paulo state, Brazil.

\section{Methods}

A total of 122 public procurement within rural family farming published electronically by 99 cities from January to September of 2013 were analyzed. The foods were classified in the following groups: grains; roots and tubers; legumes; meat; fish; vegetables; fruits; processed foods; ingredients; and milk. The cities were grouped into quartiles according to the number of elementary school students. The foods listed in the public procurement within rural family farming were then assessed according to city size. The Kruskal-Wallis test verified the difference between the number of foods in each group and in each quartile $(p<0.05)$.

\section{Results}

Of all the foods, the most common groups in the public procurement within rural family farming were the vegetable and fruit groups, representing 50 and $31 \%$, respectively. The number of foods in the groups of

\footnotetext{
1 Universidade Federal de São Paulo, Centro Colaborador em Alimentação e Nutrição Escolar, Programa de Pós-Graduação Interdisciplinar em Ciências da Saúde. Santos, SP, Brasil.

2 Universidade Federal de São Paulo, Instituto de Saúde e Sociedade, Departamento de Biociências. Santos, SP, Brasil.

3 Universidade Federal de São Paulo, Instituto de Saúde e Sociedade, Departamento de Saúde, Clínica e Instituições. R. Silva Jardim, 136, 11015-020, Santos, SP, Brasil. Correspondência para/Correspondence to: DH BANDONI. E-mail: <danielbandoni@gmail.com>.
} 
grains, legumes, and milk in the public procurement within rural family farming increased with the number of students. On the other hand, cities with fewer students acquired more foods from the fruit group, resulting in differences between the quartiles $(p<0.05)$. The group of processed foods was requested by $41 \%$ of the cities.

\section{Conclusion}

Fresh foods were the most common types of foods in the public procurement within rural family farming, demonstrating that the acquisition of family farm products can contribute to school meal quality.

Keywords: Familiar agriculture. Menu planning. School feeding.

\section{RE S U M O}

\section{Objetivo}

Avaliar o perfil dos alimentos presentes nas chamadas públicas para aquisição de alimentos da agricultura familiar para o Programa Nacional de Alimentação Escolar de municípios do estado de São Paulo.

\section{Métodos}

Foram analisadas 122 chamadas públicas de 99 municípios publicadas de janeiro à setembro por meio eletrônico. Os alimentos foram classificados nos grupos: cereais, raízes e tubérculos; leguminosas; carnes; pescado; hortaliças; frutas; processados; ingredientes; leite. Os municípios foram agrupados em quartis segundo o número de escolares matriculados na rede básica de ensino. Esse agrupamento permitiu avaliar os alimentos divulgados nas chamadas públicas considerando o porte dos municípios. Para verificar a diferença entre o número de alimentos em cada grupo e em cada um dos quartis foi utilizado o teste Kruskal-Wallis $(p<0,05)$.

\section{Resultados}

Os alimentos dos grupos de hortaliças e frutas foram os mais presentes nas chamadas públicas avaliadas, representando 50 e $31 \%$, respectivamente, do total dos alimentos. Verificou-se que, quanto maior o número de escolares, maior foi o número de alimentos pertencentes aos grupos dos cereais, das leguminosas e do leite nas chamadas públicas. Em contrapartida, os municípios com menor número de escolares adquiriram mais alimentos dos grupos das frutas, encontrando diferença significativa $(p<0,05)$, entre os quartis. Destaca-se a presença do grupo de processados em $41 \%$ dos municípios.

\section{Conclusão}

Os gêneros mais presentes nas chamadas públicas foram alimentos in natura, demonstrando que a aquisição de alimentos da agricultura familiar pode contribuir com a qualidade da refeição oferecida na alimentação escolar.

Palavras-chave: Agricultura familiar. Planejamento de cardápio. Alimentação escolar.

\section{NTRODUCTIO N}

The Programa Nacional de Alimentação Escolar (PNAE, National School Feeding Program), launched in 1955, is the oldest food and nutrition policy in force in the country ${ }^{1}$. The current objective of this program is to ensure students' food and nutrition security, providing equal access to all, and respecting age-related differences and the health conditions of those who need special care or are socially vulnerable. Based on the Human Right to Adequate Food, the program is universal and permanent in order to guarantee adequate food to all public school students ${ }^{2}$.
National School Feeding Program has been restructured and changed many times during its history, leading to important advances, especially Law $n^{\circ} 11.947$ and Resolution $n^{\circ} 38$, passed in 2009, where at least $30 \%$ of the funds provided by the Fundo Nacional de Desenvolvimento da Educação (FNDE, National Education Development Fund) must be used for acquiring foods directly from family farms and/or family entrepreneurs ${ }^{2,3}$. This legislation is considered an important milestone for the support of local sustainable development as it encourages the purchase of diverse, locally-produced foods, stimulating regional and healthy eating habits ${ }^{4}$. In order to 
promote the acquisition of these foods for school meals and considering the buying/selling difficulties reported by buyers and family farmers, the federal government published two resolutions to promote sectorial coordination and reach the goal of effectively using $30 \%$ of the FNDE funds for this purpose $e^{5,6}$.

The partnership between family farms and the PNAE has strengthened family farms, but legislation alone cannot guarantee that this relationship will promote healthy school meals ${ }^{7}$. PNAE limited the acquisition of processed foods, since eating habits acquired during childhood and adolescence are more likely to remain throughout adulthood; additionally, this limitation encouraged the intake of vegetables, fruits, and fish ${ }^{5,8}$.

Only one study in the literature assessed the profile of family farm foods present in school meals, possibly because of the difficulty of acquiring related data ${ }^{9}$. In this context, analyses of family farm food purchases or intention to purchase for school meals are important because of the need to strengthen family farms, stimulating the intake of regional foods, promoting social and biological diversity that respects local eating habits, and increasing students' intake of fresh foods, as established by PNAE guidelines ${ }^{10}$.

Hence, the objective of this study was to assess the profile of the foods listed in the public procurements within rural family farming for the acquisition of family farm foods for the National School Feeding Program in the cities of São Paulo state from January to September of 2013.

\section{METHODS}

Public procurements within rural family farming for food acquisition published by the cities in São Paulo state in 2013 were searched electronically. The following websites were consulted: Via Pública (http://www.viapublica. org.br), Rede Brasil Rural (http://www.rede brasilrural.mda.gov.br), and the official websites of city halls. Additionally, the Google search engine (www.google.com.br) was used for searching public procurements within rural family farming in other websites, using the keywords "chamada pública agricultura familiar" ("public procurement within rural family farming") limiting the search to the year of publication of 2013. Thus, all cities that had published public procurements within rural family farming and made them electronically available on the websites mentioned above or other websites located by Google's search engine were analyzed.

Resolution $n^{\circ}$ 26/2013 establishes that public procurement within rural family farming for school meals must be published in local newspapers and in murals located in busy places, along with their internet website when available. If necessary, they should be published in regional, state, and national newspapers, and announced by local radio stations and by the Rede Brasil Rura/ ${ }^{5}$. Hence, the public procurements within rural family farming were searched electronically, considering that most of them are probably published electronically, as required by law.

According to the Ministry of Agrarian Development ${ }^{11}$, public procurements within rural family farming must provide enough information for the suppliers to present their sales projects correctly. The project must include the following information: types of products and amounts supplied, delivery schedule and locations (periodicity and beginning and end of supply, among others). Then, the public procurements within rural family farming were classified as with description or without description according to the existence or not of descriptions of the food characteristics, quality, degree of ripeness, and size.

The number of public procurements within rural family farming published by each city during the study period and the total number of foods requested were also quantified. The maximum, minimum, mean, median, and standard deviation of the number of foods requested by the public 
procurements within rural family farming were also calculated.

To establish the frequency with which foods appeared in public procurements within rural family farming, different cultivars of a food constituted a single subgroup (e.g., two varieties of banana, Grand Nain and Apple, were grouped as "banana" in the public procurements within rural family farming that listed both).

The foods listed in the public procurements within rural family farming were classified according to the 2008 Brazilian Food Guide ${ }^{12}$ (which uses the food groups grains; roots, and tubers; fruits and vegetables; beans and other high-protein plant foods; milk; and meat and eggs) and to the current Brazilian Food Guide ${ }^{13}$ (which adds the groups processed and ultraprocessed foods, and ingredients). The foods were then classified into the following groups: grains (pasta, rice, and flours); roots and tubers (cassava, Arracacia xanthorrhiza, and potatoes); legumes (beans); meat (poultry, beef, pork) and eggs; fish; vegetables; fruits (including natural fruit juices); and milk ${ }^{12}$. The group of processed foods included the group of ultra-processed foods (milk-based beverages, yogurt, cheese, mini hotdog buns, sweets, cake, toasted cassava flour mix, and cookies) and ingredients (cooking oil and sugar) ${ }^{13}$.

The presence of regional, organic and/or agroecological foods were also investigated, since buyers from family farms must prioritize the purchase of these foods ${ }^{5,6}$.

The cities were grouped into quartiles according to the number of elementary school students reported in the 2013 School Census ${ }^{14}$. This grouping allowed verifying whether city size influenced the food groups requested by public procurement within rural family farming.

The nonparametric Kruskal-Wallis test performed by the software Statistical Sciences Package for the Social Sciences (SPSS Inc., Chicago, Illinois, United States) version 15.0 determined whether the food groups differed by quartile $(p<0.05)$.
RE S U L T S

A total of 122 public procurements within rural family farming published between January and September of 2013 by 99 cities in São Paulo state were analyzed. Seventy-five cities (75.75\%) described the foods properly by specifying the purchasing conditions, such as degree of ripeness, size, and other characteristics. These descriptions ensure that the delivered product will meet the expectation of the dietician who planned the menu, based on the condition of the food.

Figure 1 shows the percentage of the cities that published 1, 2, 3, 4, 5, and 6 public procurements within rural family farming during the study period. Most cities (85.80\%) published only one public procurement within rural family farming. The city that published six public procurements within rural family farming had the highest number of students and bought numerous foods, so it chose to publish many public procurements within rural family farming throughout the year requesting only one food.

The public procurements within rural family farming had a total of 2,399 foods of 122 types. The smallest number of foods requested was one and the highest was 60; the mean was 24.23 (standard deviation \pm 14.38 ), and the median, 23 .

The 20 foods most commonly requested by the public procurements within rural family

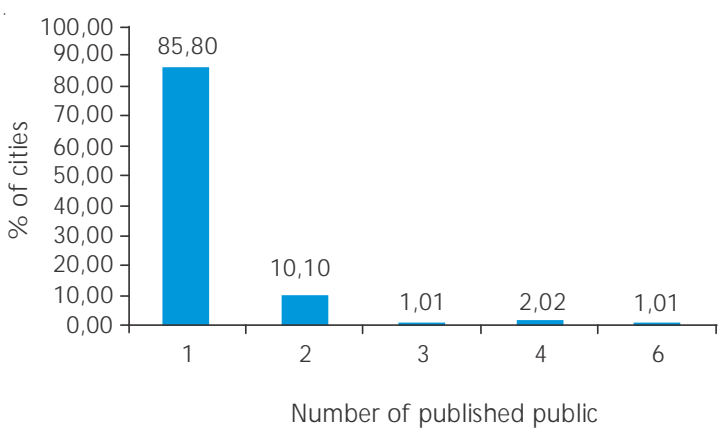

Figure 1. Percentage of cities by the number of published public procurements within rural family farming. São Paulo (SP), Brazil, 2013. 
farming were from the vegetable, fruit, and tuber groups (Table 1).

Regarding regional and organic and/or agroecological foods, one public procurement within rural family farming requested regional foods and another, organic and/or agroecological foods. The regional food was cambuci (Campomanesia phaea Berg.) ${ }^{15}$, a fruit native to the Atlantic Forest found in São Paulo's metropolitan region and Serra do Mar, and the organic food was rice.

The quartiles had the following cut-offs: the first quartile consisted of cities with up to 1,715 students; the second quartile consisted of cities with 1,778 to 5,095 students; the third quartile consisted of cities with 5,463 to 12,923 students; and the fourth quartile, cities with 13,466 students or more.

Table 2 shows the frequency of foods requested by the public procurements within rural family farming based on food group classification and comparison between quartiles. The groups of vegetables and fruits were the most requested in all quartiles, composing 50 and 31\%, respectively, of all the foods requested. The fourth quartile, which has the highest number of students, made fewer requests for fruits and more for grains, legumes, processed foods and ingredients, with a significant difference $(p<0.05)$ for grains, legumes, and fruits.

Table 1. List of the twenty foods requested most often by the public procurements within rural family farming. São Paulo (SP), Brazil, 2013.

\begin{tabular}{lcc}
\hline & \multicolumn{2}{c}{$\begin{array}{c}\text { Public procurement within } \\
\text { rural family farming }\end{array}$} \\
\cline { 2 - 3 } & $\mathrm{n}$ & $\%$ \\
\hline Lettuce & 82 & 67.21 \\
Banana & 81 & 66.39 \\
Tomato & 76 & 62.29 \\
Carrot & 74 & 60.65 \\
Beet & 73 & 59.83 \\
Kale & 73 & 59.83 \\
Parsley & 70 & 57.37 \\
Cabbage & 70 & 57.37 \\
Orange & 66 & 54.09 \\
Zucchini & 65 & 53.27 \\
Cucumber & 65 & 53.27 \\
Cassava & 59 & 48.36 \\
Chayote & 58 & 47.54 \\
Green bean & 53 & 43.44 \\
Potato & 51 & 41.80 \\
Papaya & 51 & 41.80 \\
Chard & 48 & 39.34 \\
Onion & 48 & 39.34 \\
Watermelon & 48 & 39.34 \\
Pumpkin & 34.42 \\
\hline & &
\end{tabular}

Table 2. Frequency of foods requested by public procurements within rural family farming published by the cities in São Paulo state by quartiles of number of students. São Paulo (SP), Brazil, 2013.

\begin{tabular}{|c|c|c|c|c|c|c|c|c|c|c|c|}
\hline \multirow[t]{2}{*}{ Food frequency } & \multicolumn{2}{|c|}{$\begin{array}{c}1^{\text {st }} \text { Quartile } \\
(n=25)\end{array}$} & \multicolumn{2}{|c|}{$\begin{array}{c}2^{\text {st }} \text { Quartile } \\
\quad(n=25)\end{array}$} & \multicolumn{2}{|c|}{$\begin{array}{c}3^{\text {st }} \text { Quartile } \\
(n=24)\end{array}$} & \multicolumn{2}{|c|}{$\begin{array}{c}4^{\text {st }} \text { Quartile } \\
\qquad(n=25)\end{array}$} & \multicolumn{2}{|c|}{$\begin{array}{c}\text { Total } \\
(n=99)\end{array}$} & \multirow{2}{*}{$p$} \\
\hline & $n$ & $\%$ & $n$ & $\%$ & $n$ & $\%$ & $n$ & $\%$ & $n$ & $\%$ & \\
\hline Grains* $^{*}$ & 4 & 0.59 & 5 & 0.82 & 17 & 2.75 & 35 & 7.09 & 61 & 2.54 & 0.000 \\
\hline Roots and tubers & 60 & 8.86 & 52 & 8.52 & 42 & 6.80 & 37 & 7.49 & 191 & 7.96 & 0.055 \\
\hline Legumes* & 2 & 0.29 & 8 & 1.31 & 8 & 1.29 & 16 & 3.24 & 34 & 1.42 & 0.050 \\
\hline Meat & 9 & 1.33 & 12 & 1.97 & 13 & 2.10 & 5 & 1.01 & 39 & 1.63 & 0.073 \\
\hline Fish & 1 & 0.15 & 4 & 0.66 & 1 & 0.16 & 0 & 0.00 & 6 & 0.25 & 0.265 \\
\hline Vegetables & 336 & 49.63 & 322 & 52.79 & 326 & 52.75 & 219 & 44.33 & 1,203 & 50.15 & 0.083 \\
\hline Fruits $^{*}$ & 249 & 36.78 & 181 & 29.67 & 173 & 27.99 & 142 & 28.75 & 745 & 31.05 & 0.018 \\
\hline Processed foods & 14 & 2.07 & 20 & 3.28 & 25 & 4.05 & 28 & 5.67 & 87 & 3.63 & 0.082 \\
\hline Ingredients & 0 & 0.00 & 1 & 0.16 & 4 & 0.65 & 6 & 1.21 & 11 & 0.46 & 0.153 \\
\hline Milk & 2 & 0.30 & 5 & 0.82 & 9 & 1.46 & 6 & 1.21 & 22 & 0.92 & 0.069 \\
\hline Total & 677 & 28.22 & 610 & 25.43 & 618 & 25.76 & 494 & 20.59 & 2,399 & 100.00 & \\
\hline
\end{tabular}

Note: ${ }^{*} p<0.05$ in the Kruskal-Wallis test, which compared the number of foods requested by the calls for bids without invitation for bid in different quartiles. 
The presence of processed foods challenges PNAE's guideline of buying foods from family farms, which regards healthy and basic foods. The percentage of this group was generally higher than those of grains, legumes, meat and eggs, fish, ingredients, and milk. This group was requested by $41(41.42 \%)$ cities.

Seventeen (17.17\%) and seven (7.07\%) cities did not request vegetables and fruits, respectively, in the public procurements within rural family farming (data not shown). Larger cities (fourth quartile) were less likely to request these food groups. Ten $(10.10 \%)$ cities in the fourth quartile did not request vegetables, and 4 (4.04\%) did not request fruits and juices. Fish was requested by $4(4.04 \%)$ cities.

Of all the cities, eighteen (18.18\%) requested natural fruit juices, and five of them only requested fruits as juice. These cities had the highest number of students: 2 (2.02\%) were in the third quartile, and $3(3.03 \%)$ were in the fourth quartile. Furthermore, these five cities did not request vegetables, demonstrating the difficulty of large cities to acquire foods from the fruit and vegetable groups and their preference for natural fruit juice, which is packed individually, facilitating logistics and storage.

\section{DISCUSSION}

This study analyzed the foods requested by public procurements within rural family farming published between January and September of 2013 to acquire family farm products for school meals. Most types of foods requested by these public procurements within rural family farming were fresh foods, especially vegetables, fruits, and tubers.

According to data from PNAE/FNDE's instrument for cities and states to render accounts, in 2010 47.4\% of the Brazilian cities acquired foods from family farms, and the average expense spent with these foods represented $22.7 \%$ of the total funds transferred by FNDE for school meals ${ }^{10}$.
Villar et al. ${ }^{4}$ investigated the status of the cities in São Paulo state regarding the acquisition of these products from June to August of 2011 and found that $288(47.0 \%)$ cities had already purchased foods from local family farms before.

Public procurements within rural family farming with the description of the requested foods, receive higher quality foods. Triches \& Schneider ${ }^{16}$ studied the relationship between consumption, production, and food-related public policies based on the PNAE and found that some cities have used PNAE to bring buyers and producers closer together, and one of the means used for this purpose is to provide specific product characteristics: organic, ecological, without pesticides, without chemical additives, traditional, handcrafted, and free range, among others. Most cities $(75.75 \%)$ described the food characteristics, but $24.25 \%$ of the cities must be advised about the importance of a detailed public procurement within rural family farming, describing the characteristics of the foods and including other essential information (amount with the respective unit). Still regarding food description, Bandoni et al. ${ }^{17}$ assessed 122 public procurements within rural family farming and found that the microbiological, physical, chemical, microscopic, and toxicological characteristics of the foods and transportation conditions specified in those public procurements within rural family farming were not sufficiently detailed.

There are no norms specifying the maximum or minimum number of public procurements within rural family farming published within a year, but more than one should be published because of product seasonality and price.

The twenty foods most often found in the public procurements within rural family farming were in the groups of vegetables, fruits, and tubers. Similar results were reported by Triches \& Schneider ${ }^{16}$ who conducted a case study of the experience in the cities of Rolante and Dois Rios, both in the state of Rio Grande do Sul, and found that foods acquired directly from family farms for the PNAE changed the students' eating habits and conceptions. 
This fact was provided through the cooks' statement, who reported receiving fresh foods more often, greater variety, and better quality, improving students' food acceptance and consumption.

Toyoyoshi et al. ${ }^{9}$ assessed cities that participated in 2011's Prêmio Gestor Eficiente (Efficient Manager Prize) conducted by the nongovernmental organization Ação Fome Zero (Zero Hunger Program) and found that 19 of the 22 winning cities acquired foods from family farms. Of these, three acquired regional products: pequi (Caryocar brasiliense) (Mato Grosso), taioba (Xanthosoma sagittifolium) (Minas Gerais), caruru (Amaranthus species) and jambo (Syzygium jambos) (Pará), and two other cities from the states of Paraíba (PB) and Ceará (CE) acquired organic foods, corroborating the results observed by the present study in which public procurements within rural family farming rarely request regional and organic foods. Monego et al..$^{18}$ investigated the production and the production potential of vegetables and fruits native to the Cerrado (tropical savanna) in the state of Goiás and Federal District to promote their inclusion in school meals and found that the production of regional foods is challenging for small farmers. Regarding organic foods, Silva \& Sousa ${ }^{19}$ conducted a descriptive study to determine which cities in the state of Santa Catarina had acquired organic family farm foods in 2010 and found that 9 (17.7\%) out of 52 cities had.

The same study by Toyoyoshi et al. ${ }^{9}$, the only study in the literature that assessed the profile of foods acquired from family farms, found that the food groups most acquired by $83.0 \%$ of the 19 winning cities were fruits/pulps and vegetables, a result similar to that of the present study despite the use of different methods. One can infer that family farm products can encourage students to consume fruits and vegetables, a consumption that is still low as pointed out by Levy et al. ${ }^{20}$, who analyzed data from the Pesquisa Nacional de Saúde do Escolar (PeNSE, National Student Health Survey) to determine how often students consumed eight foods, food groups, or preparations, and found that $21.0 \%$ of the students did not consume fruits, and $26.8 \%$ did not consume vegetables at all. Still with respect to the intake of these foods, Costa et al. ${ }^{21}$ estimated the frequency and factors associated with the adequate intake of fruits and vegetables by students from the state of Santa Catarina and found that the average intake of fruits and vegetables was 1.5 times/day and the one of sweets was 2.0 times/day. Only 133 (2.7\%) students had the proper intake of fruits and vegetables ( $\geq 5$ times/day), while 1,319 (26.6\%) did not consume these foods at all. The number of individuals who did not consume fruits ( $n=2,390 ; 48.1 \%$ ) was similar to the one which did not consume vegetables $(n=2,300 ; 46.3 \%)^{21}$.

Larger cities made fewer requests for fruits and vegetables in their public procurements within rural family farming. One of the reasons for this is that greater amounts of these food groups are needed for these cities to effectively spend $30 \%$ of the resources provided by FNDE for the acquisition of family farm products ${ }^{7}$. This may be due to the cities' difficulty of receiving, storing, and distributing these food groups. And besides, large cities need large amounts of foods, which can only be supplied by cooperatives with high production volumes. Sousa et al..$^{22}$ reported that the logistics needed by a family farm to meet PNAE demands in large urban areas depend on complex and costly schemes; it is a challenge for family farmers to outbid distributors and wholesalers from the conventional food supply system.

Processed foods were requested by the public procurements within rural family farming of $41.42 \%$ of the cities. This percentage was generally higher than those of grains, legumes, meat and eggs, fish, ingredients, and milk. Toyoyoshi et al. ${ }^{9}$ also found many requests for sweets $(52.63 \%)$, explaining that this can be because of the food habits and preferences of regional cultures. Family entrepreneurs produce these processed/ultra-processed foods by 
aggregating value to simpler products, making them more expensive; concomitantly, these foods are both easy and ready to consume and are unhealthy, as affirmed by Louzada et al. ${ }^{23}$, who found that ultra-processed foods tend to have a lower micronutrient content than other foods, with an even greater difference when ultraprocessed foods are compared to fresh or minimally processed foods.

The Pesquisa de Orçamento Familiar (Household Budget Survey) of 2008-2009 found that Brazilians aged ten or more consume a mean of 1,866 kcal per day; $9.0 \%$ of this energy comes from processed foods and $21.5 \%$ comes from ultra-processed foods ${ }^{24}$. Therefore, coordinated public policies are needed to create actions to reduce the intake of these foods, especially in schools, regardless whether they are supplied by family farms or not.

Processed/ultra-processed family farm foods, such as yogurt, milk-based beverages, sweets (fudge, banana sweet, paste of various flavors), cookies, and toasted cassava flour mix do not need to be consumed in schools. However, the higher price of these foods can help cities reach the $30 \%$ of the FNDE funds that must be spent on family farm products.

According to its legal framework, the acquisition of family farm foods for school meals, aims to encourage healthy and culturally coordinated eating habits that promote Brazilian students' health and local development. Supplying school meals based on fresh or minimally processed foods, preferably organic, agroecological, or socially and biologically diverse is an important measure for meeting the PNAE guidelines.

Teo \& Monteiro ${ }^{7}$ reported that, family farms were not at first prepared to supply schools as this would require producer organization and the support of agricultural entities for their production to meet the school food demand and for it to be centered on basic, unrestricted and [PNAE restricts the purchase of canned products, sausages, sweets, combinations (two or more products packaged separately but consumed together), semi-ready-to-consume or ready-toconsume foods, and concentrated foods (powders or dehydrated products], unprocessed foods in the proper and necessary amounts. At the same time, the health and education areas must discuss the PNAE with family farmers in an interdisciplinary process to share the vision of the program, getting closer to them in order to promote advances for both parties.

\section{CONCLUSION}

The public procurements within rural family farming for acquiring family farm foods for school meals published between January and September of 2013 by the cities in São Paulo state requested mostly fresh foods, especially vegetables and fruits. Cities with the smallest number of students requested fruits more often and in greater variety of foods. Hence, future studies should investigate the difficulties large cities face to purchase fresh foods, encourage fresh food production and acquisition, and propose actions that facilitate the logistics of delivering fresh foods. On the other hand, the legal requirement of spending $30 \%$ of FNDE funds on family farm products should be bound to the supply of healthy foods and the restriction of processed foods. The acquisition of family farm foods can contribute to the quality of school meals, promoting a greater supply and variety of fresh foods.

\section{CONTRIBUTORS}

ALB AMORIM analyzed and interpreted the data and wrote the article. WV ROSSO analyzed and interpreted the data and wrote the article. DH BANDONI analyzed and interpreted the data and wrote the article.

\section{REFERE N CE S}

1. Belik W, Chaim NA. O programa nacional de alimentação escolar e a gestão municipal: eficiência 
administrativa, controle social e desenvolvimento local. Rev Nutr. 2009; 22(5):595-607. http://dx. doi.org/10.1590/S1415-52732009000500001

2. Brasil. Presidência da República. Lei n 11.947, de 16 de junho de 2009. Dispõe sobre o atendimento da alimentação escolar e do Programa Dinheiro Direto na Escola. Diário Oficial da União. 200917 jun; p.2.

3. Fundo Nacional de Desenvolvimento da Educação. Resolução CD/FNDE n 38, de 16 de julho de 2009. Dispõe sobre o atendimento da alimentação escolar aos alunos da educação básica no Programa Nacional de Alimentação Escolar - PNAE. Brasília: FNDE; 2009.

4. Villar BS, Schwartzman F, Januario BF, Ramos JF. Situação dos municípios do estado de São Paulo com relação à compra direta de produtos da agricultura familiar para o Programa Nacional de Alimentação Escolar (PNAE). Rev Bras Epidemiol. 2013; 16(1):223-6. http://dx.doi.org/10.1590/S14 15-790X2013000100021

5. Fundo Nacional de Desenvolvimento da Educação. Resolução CD/FNDE n² 26, de 17 de junho de 2013. Dispõe sobre o atendimento da alimentação escolar aos alunos da educação básica no âmbito do Programa Nacional de Alimentação Escolar - PNAE. Brasília: FNDE; 2013.

6. Fundo Nacional de Desenvolvimento da Educação. Resolução CD/FNDE n 04, de 2 de abril de 2015. Altera a redação dos artigos 25 a 32 da Resolução/ CD/FNDE n²6, de 17 de junho de 2013, no âmbito do Programa Nacional de Alimentação Escolar (PNAE). Brasília: FNDE; 2015.

7. Teo CRPA, Monteiro CA. Marco legal do Programa Nacional de Alimentação Escolar: uma releitura para alinhar propósitos e práticas na aquisição de alimentos. Rev Nutr. 2012; 25(5):657-68. http://dx. doi.org/10.1590/S1415-52732012000500010

8. Fundo Nacional de Desenvolvimento da Educação. Inclusão do pescado na alimentação escolar. Nota Técnica n². Brasília: FNDE; 2013.

9. Toyoyoshi JY, Oliveira R, Santos MSN, Galisa MS, Galante AP. Avaliação da aquisição de gêneros alimentícios provenientes da agricultura familiar para a alimentação escolar. Mundo Saúde. 2013; 37(3):329-35.

10. Saraiva EL, Silva APF, Sousa AA, Cerqueira GF, Chagas CMS, Toral N. Panorama da compra de alimentos da agricultura familiar para o Programa Nacional de Alimentação Escolar. Ciênc Saúde Colet. 2013; 18(4):927-36. http://dx.doi.org/10.15 90/S1413-81232013000400004
11. Brasil. Ministério do Desenvolvimento Agrário. Passo a passo: como funciona a compra e venda de produtos da Agricultura Familiar. Brasília: Ministério do Desenvolvimento Agrário; 2013 [acesso 2013 nov 4]. Disponível em: http://comunidades. mda.gov.br/portal/saf/institucional/3\% C 2\% BA_Passo

12. Brasil. Ministério da Saúde. Secretaria de Atenção à Saúde. Guia alimentar para a população brasileira: promovendo a alimentação saudável. Brasília: Ministério da Saúde; 2008.

13. Brasil. Ministério da Saúde. Secretaria de Atenção à Saúde. Guia alimentar para a população brasileira. $2^{a}$ ed. Brasília: Ministério da Saúde; 2014.

14. Fundo Nacional de Desenvolvimento da Educação. Consulta censo escolar 2013. Brasília: FNDE; 2013 [acesso 2013 out 15]. Disponível em: http://www. fnde.gov.br/financiamento/fundeb/fundeb-consultas

15. InfoEscola: navegando e aprendendo. Cambuci. [acesso 2013 nov 10]. Disponível em: http://www. infoescola.com/frutas/cambuci

16. Triches RM, Schneider S. Alimentação escolar e agricultura familiar: reconectando o consumo à produção. Saúde Soc. 2010; 19(4):933-45. http://dx. doi.org/10.1590/S0104-12902010000400019

17. Bandoni DH, Stedefeldt E, de Amorim ALB, Barbosa HV, de Rosso VV. Regulação sanitária na agricultura familiar para a alimentação escolar. Vig Sanit Debate. 2014; 2(4):107-14. http://dx.doi.org/ 10.3395ND.V214.473

18. Monego ET, Alexandre VP, Sousa LM, Martins KA, Rosa JQS, Souza PLC, et al. Produção e potencial agrícolas de alimentos destinados à alimentação escolar em Goiás e no Distrito Federal, na Região Centro-Oeste do Brasil. Rev Nutr. 2013; 26(2):233-41. http://dx.doi.org/10.1590/S1415-52732013000 200011

19. Silva APF, Sousa AA. Alimentos orgânicos da agricultura familiar no Programa Nacional de alimentação Escolar do Estado de Santa Catarina, Brasil. Rev Nutr. 2013; 26(6):701-14. http://dx.doi. org/10.1590/S1415-52732013000600009

20. Levy RB, Castro IRR, Cardoso LO, Tavares LF, Sardinha LMV, Gomes FS, et al. Consumo e comportamento alimentar entre adolescentes brasileiros: Pesquisa Nacional de Saúde do Escolar (PeNSE), 2009. Ciênc Saúde Colet. 2010; 15(2): 3085-97. http://dx.doi.org/10.1590/S1413-81232 010000800013

21. Costa LCF, Vasconcelos FAG, Corso ACT. Fatores associados ao consumo adequado de frutas e hortaliças em escolares de Santa Catarina, Brasil. 
Cad Saúde Pública. 2012; 28(6):1133-42. http:// dx.doi.org/10.1590/S0102-311X2012000600012

22. Sousa AA, Silva APF, Azevedo E, Ramos MO. Cardápios e sustentabilidade: ensaio sobre as diretrizes do Programa Nacional de Alimentação Escolar. Rev Nutr. 2015; 28(2):217-29. http:// dx.doi.org/10.1590/1415-52732015000200010

23. Louzada MLC, Martins APB, Canella DS, Baraldi LG, Levy RB, Claro RM, et al. Impacto de alimentos ultraprocessados sobre o teor de micronutrientes da dieta no Brasil. Rev Saúde Pública. 2015; 49:45.
http://dx.doi.org/10.1590/S0034-8910.2015 049006211

24. Louzada MLC, Martins APB, Canella DS, Baraldi LG, Levy RB, Claro RM, et al. Alimentos ultraprocessados e perfil nutricional da dieta no Brasil. Rev Saúde Pública. 2015; 49:38. http://dx.doi.org/ 10.1590/S0034-8910.2015049006132

Received: July 22, 2014

Final version: August 19, 2015

Approved: November 26, 2015 